\title{
(Non-)Belonging in the Context of War and Migration: Reconstructing the Self-Examinations of a 1.5 Generation Refugee
}

\author{
Ana Mijić
}

\section{Introduction}

Almost thirty years have passed since the violent breakup of the Socialist Federal Republic of Yugoslavia; subsequent wars reached their tragic climax in BosniaHerzegovina, where approximately 100,000 people were killed and over two million displaced. 1.2 million people fled the country as war refugees and sought shelter in over 20 different nation states. Nearly 90,000 came to Austria (Valenta/Ramet 2011a: 4), where they were accepted as "de facto refugees" (Halilovich et al. 2018: 97). 1998, three years after the end of the war, most of these former refugees had been granted permanent residence status (Franz 2005, 2011; Hageboutros 2016; Halilovich 2013; Halilovich et al. 2018). They stayed in Austria and assimilated, at least statistically, with the large number of 'guest workers' who had been in Austria since the 1960 s or 1970 s.

Ex-Yugoslavian migrants, primarily Bosnian refugees, have been the subject of much research, most of which focuses on analyzing how receiving countries responded to them; it reflects on or compares different reception policies and/or addresses the issue of refugee integration into the host nations' existing structures 
(Franz 2005, 2011; Halilovich 2013; Halilovich et al. 2018; Valenta/Ramet 2011b). However, in a project currently in process at the University of Vienna, I am focusing on identity formations in the Bosnian diaspora(s) within Austria (or in Vienna). According to the project's initial presupposition, wartime, the postwar period, and migration constitute a very particular and tense context of experience within which immigrants from Bosnia-Herzegovina and their descendants have had to (re-)construct their self-images (their individual identities, as well as their collective belonging).

During the war between 1992 and 1995, people from Bosnia-Herzegovina were exposed to an accelerated ethnic mobilization, which was accompanied by a reduction of identity to ethnic belonging, and by the "extermination of alternative identity choices" (Verdery 1994: 38; Ignatieff 1994; Mijić 2014; Wimmer 2008: 982). This reduction resulted in prolonged ethnic nationalism, not only in Bosnia, but also within the Bosnian and ex-Yugoslavian diasporas worldwide (Bock-Luna 2007; Colic-Preisker 2006; Pryke 2003). However, it can be expected that experiences of migration and life in minority settings have had further effects on Bosnian emigrants' identities. Expanding upon the sociology of knowledge perspective, the following question emerges: What happens when people find themselves in a situation where their "thinking as usual" no longer works (or where it is contested by alternative perceptions of reality)?1 Within the context of the sociology of knowledge, as developed by Peter L. Berger and Thomas Luckmann in "The Social Construction of Reality" (1966), my study addresses the question of how the experience of war and the experience of migration 'co-shape' the identities of Bosnians living in Austria; it explores the relevance of ethnic belonging and analyzes how people deal with crises arising from their experiences of war and migration. I have conducted narrativebiographical interviews (Schütze 1976; Rosenthal 2004) to empirically examine strategies of identity (re-)construction, and I have analyzed the interviews using 'objective hermeneutics' - a reconstructive methodology developed by Ulrich Oevermann (Oevermann/Allert/Konau 1980).

In this chapter, I approach the subject of identity and belonging by analyzing the (biographical) identity of a Viennese woman who came to Austria during the first months of the Bosnian War in 1992 at the age of six. In the literature, people who experienced (forced) migration during childhood are occasionally referred to as belonging to the 1.5 generation (Rumbaut 1976, 2004). Unlike second-generation migrants, 1.5 generation migrants actually experienced migration first-hand. However, they had this experience in a 'premature' life stage, or as Berger and Luckmann describe it, before their primary socialization had been concluded (Berger/Luckmann 1966: 150).

\footnotetext{
1 On a theoretical level, Alfred Schütz elaborated on this question in his essay on "The Stranger" (Schütz 1944). This essay gives important social phenomenological insights into the challenges of adapting to a new social environment and reflects on processes of knowledge transformation and on what Karl Mannheim has described as 'relationism' (Mannheim 1985: 258 f.).
} 
I will first outline the key points of my study's theoretical background in order to specify the question guiding the analysis presented in this chapter. This part is followed by a short description of the data and the methodology. Finally, I will present the most prominent lines of interpretation and the results of the analyses, i.e., the reconstructed case structure.

\section{Theoretical Foundation}

While the starting point is the individual biography, the analysis comprises more than what is usually referred to as the 'micro-level'. By combining the 'sociologies' of Max Weber and Émile Durkheim, Berger and Luckmann address a central question of sociological theory: "How is it possible that subjective meanings become objective facticities? ... How is it possible that human activity (Handeln) should produce a world of things (choses)?” (Berger/Luckmann 1966: 18). They base their work on a fundamental (dialectical) proposition: "Society is a human product. Society is an objective reality. Man is a social product" (ibid.: 61). This ongoing dialectical process is composed of the three moments of externalization, objectivation, and internalization, whereas "knowledge $\ldots$ is at the heart of [this] fundamental dialectic" (ibid.: 82 f.).

Externalization indicates how a person "projects his or her own meanings into reality" (ibid.: 104); objectivation refers to how subjective knowledge is turned into objective or institutional knowledge; and, internalization means the subjective integration of these objective realities within processes of socialization (the objective realities must become subjectively meaningful to an individual). Primary socialization is the first step with which an individual becomes a member of society. It is characterized by a highly emotional relationship with significant others. Any following process that introduces an already-socialized individual to new sectors of the objective world is characterized as secondary socialization (ibid.: 130). During this socialization, individuals not only learn how their significant others see the world: they learn that this is how this world quite simply is - they internalize the world of their significant others as the only reality - and they also learn who they are.

Berger and Luckmann's concept of identity is distinct from other approaches, as it avoids one central pitfall of identity research (Mijić 2018). Brubaker and Cooper, for instance, point out that identity "is too ambiguous, too torn between 'hard' and 'soft' meanings, essentialist connotations and constructivist qualifiers, to serve well the demands of social analysis" (Brubaker/Cooper 2000: 2). While the "hard" conceptions emphasize a fundamental consistency and essentialize or reify identity, constructivist approaches oppose this essentialism and accentuate the social origin, the preliminary, and processual character of identity. Whereas the former must be considered as scientifically untenable, the latter may be, to Brubaker and Cooper, "too weak to do useful theoretical work" (ibid.: 11). Berger and Luckmann's assumption of a "fundamental social dialectic" (Berger/Luckmann 1966: 61), however, resolves 
the dilemma, since it conceives social reality and, accordingly, identity as a human product and "objective facticity" (ibid.: 159). It is "subjective meaning" (Weber 1921) as well as a "social fact" (Durkheim 1895). In other words, despite being socially constructed, identity must not be considered as completely volatile.

These theoretical assumptions also apply mutatis mutandis to what is commonly denoted as 'collective identity' or 'we-identity' (Elias 2001) and thus to questions of belonging: for instance, with regard to ethnicity or, more precisely, ethnic boundaries. They are socially created, but once objectified, they become social facts, which cannot simply be ignored or wished away. This became most clearly apparent in the course of the violent conflict in Bosnia. Against the backdrop of The Social Construction of Reality, it is possible to say theoretically that the notions of "participants' primordialism" (Brubaker 2004: 9) and ethnicity as constructed are not contradictory. By using the idea of social construction, we can analyze the processes by which ethnicity becomes essentialized (Mijić 2014; Müller/Zifonun 2010).

\section{Data and Methods}

The analysis of the biographical identities of 1.5 generation Bosnian-Austrians draws on the objective hermeneutical interpretation of narrative interviews. The latter are characterized by the interviewees not being confronted with closed questions, but rather encouraged to narrate stories.

The interviews were analyzed using 'objective hermeneutics' - a reconstructive methodology developed by Ulrich Oevermann. Objective hermeneutics is considered the most promising method to analyze 'identity' in the context of crisis - here: the context of war and migration - since unlike different types of content analysis, this approach does not focus on the information content of a text (such as an interview), but on the reconstruction of a specific case structure. In other words, the primary interest is not to uncover what people are talking about but how they talk about specific topics and in which ways they express them. Furthermore, this approach does not ask about the speaker's intention, i.e., it considers not the subjective sense, but the 'objective' meaning of the text. The key strength of objective hermeneutics is its capacity to uncover the 'how' - the structures or 'strategies' that people deploy unconsciously in the face of specific challenges or crises, and that cannot be ascertained by asking direct questions. By reconstructing the latent meaning structures, we can also reveal social interpretation patterns, i.e., commonly shared, widespread, and stable (world)views and understandings within a community or society.

The first step in an objective hermeneutical analysis entails (in some cases, but not all) extracting and interpreting the objective data from an interview, i.e., analyzing a person's social background (Oevermann/Allert/Konau 1980). The second step involves the sequential fine analysis of the beginning of the interview. The expectation is that the 'motto' - or central feature - of a life story is most prominent in the very first moments of an interview. After identifying a case structure and 
developing a case structure hypothesis, further text units are selected, usually using maximum variation sampling. Saturation is reached when further text unit analysis does not significantly change the structure hypothesis.

In this chapter, I present the case of Nadija Savić ${ }^{2}$ as a significant example of how war and migration (as well as life in a minority setting) are experienced by an individual who was forced to migrate during her childhood and how these experiences are processed in the construction of her individual and collective identity. During the interview, it was particularly striking that she rarely recounted events, but rather reflected on her life - despite the interview's narrative approach and multiple attempts by the interviewer to provoke narratives. I chose to include this observation in the analysis and to raise the question of how Nadija reflects on identity and belonging. In other words, my aim was to reconstruct her self-examinations. Therefore, I decided to address the objective data only very briefly and to focus chiefly on the text analysis. Not least due to the length of the analysis, portraying each individual step of the objective hermeneutical reconstruction would go beyond the scope of this chapter. Instead, I focus on the most prominent lines of interpretation and the results of the analysis, i.e., the reconstructed case structure.

\section{Analysis: Fragmented Experiences and Incomplete Belongingness}

\subsection{Objective Data}

Nadija Savić was born in 1986 in the former Socialist Republic of Yugoslavia in a town (hereinafter referred to as $\mathrm{H}$.) in north-eastern Bosnia-Herzegovina, located at the Drina River, which marks the border with Serbia. Her grandparents, parents, and most of her relatives are all from this town. Her parents studied in Tuzla and Sarajevo, then moved back to H. after graduation (her mother graduated in economics, and her father in electrical engineering). Nadija also has a sister, who is two years older. At age three, Nadija started to attend kindergarten, while both of her parents were working. In the spring of 1992, she and her family experienced the Serbian occupation of their hometown by paramilitary groups, and how at least parts of the town's Serbian population turned against their Muslim fellow citizens, to whom Nadija's family belong (even though her parents are non-religious). In April 1992, shortly after the beginning of the Bosnian War and only days after her sixth birthday, she and her family fled first to Serbia and then, after a couple of weeks, through Hungary to Austria. Her parents initially intended to go to Vienna. However, upon arriving in Austria, they decided to register at an initial accommodation center in the state of Burgenland. They were placed alongside other Bosnians in a refugee camp,

2 For reasons of anonymity, I have changed the name. The interview was conducted in German in April 2016. 
where they stayed for two years. In the fall of 1992, Nadija was enrolled at a local elementary school. Her mother started to work as a cleaner, and her father as a construction worker. In 1996, only a few months after the 1995 Dayton Peace Agreement ended the Bosnian War, the family visited Bosnia-Herzegovina for the first time since fleeing. Some of their relatives who had also been refugees in Austria decided to move back to Bosnia. However, Nadija's family moved within Burgenland several times, where Nadija finished middle school and enrolled in a secondary school (Gymnasium), before the family moved to Vienna in 2001. In 2002, Nadija started a relationship with a young man in Sarajevo, which lasted two years. In 2003, she graduated from secondary school and enrolled in a natural sciences program at a Viennese University. She met her current partner, who grew up in BosniaHerzegovina, in 2004.

\subsection{The Knowing of Not Knowing}

This is the opening sequence from the interview with Nadija Savić:

Yes, ((short laughter)) so, I was born in Bosnia, and when I was six years old, we came to Austria, that is ah all my memories are just, ah, from ah, my childhood, and that=is, a little bit difficult since $=\mathrm{I}$ ah, in some cases don't know ah, which things I ah can really remember and which things I patched together from stories or from photographs, ah we, thus, I have a sister an older one and a, my parents we have lived in an apartment in H. that's in, ah in Eastern Bosnia, located directly at the Drina, a:nd, ahm, yes it is a small town, ah, and (1) practically my whole closer family was in H., ahm, that is my grandparents first of all, and (1) yes, and my own memories are really just a few. I went there to kindergarten a:nd, both of my parents were working (1) ahm, yes and most of the the the things I know from before are simply stories from my parents they were very close to the town they have both studied in, a Tuzla and Sarajevo and both decided to come back to $H$. ... since their whole circle of friends went back as well all of them have studied in Belgrade or Sarajevo or Tuzla //mhm// and, for them this place of reference was very important, and thus, for many years I had also a very idealized notion of $\mathrm{H}$. that it is the most terrific ..., so the most terrific town in the world (laughs)) $/ / \mathrm{mhm} / /$ so I ..., I always struggle to say city, they always called it a city and it is, however, I can't say how many citizens H. has had, but, it is now for Western European standards a small town ((laughs)).

Nadija starts her reflection with an affirmation ("yes") and short laughter. It can be assumed that she understood the question. The laughter indicates that she is either overwhelmed by the question or slightly nervous. In the next sentence, she mentions two decisive aspects of her biography: her birthplace and her age when 'they' ('we') migrated (she experienced migration within a social group). She reveals herself immediately as being a 1.5 generation migrant. The time between her birth and the migration remains - for the time being - a black box. The continuation "that is" indicates that the fact she was born in Bosnia - and/or that "they" migrated to Austria when she was six years old - helps explain something: it explains that 'all her 
memories are from her childhood'. Taken literally, this means that she does not have any memories of the time after her childhood. Her subsequent deliberations, however, suggest that she is actually talking about her Bosnian memories. Thus, the way she talks about them indicates that these memories are the only ones that matter at least in the context of the present interaction. She assesses the fact that her memories of Bosnia are childhood memories as "a little bit difficult", since she is not able to distinguish between her own memories and the memories of others. She does not know for sure - "which things [she] can really remember" - what she has truly experienced, and what memories are socially derived from the stories of other sources. To Nadija, the differentiation between her own memories and the memories of others seems to be of critical importance.

The phrasing "I've patched together" indicates quite clearly that Nadija actually has (or had) a childhood 'story' and that it was her responsibility to create it; it was not delivered to her as a whole. She rather combined bits and pieces to form a coherent narrative. Asked about her life story (during the narrative interview), she does not retell this story; rather, she calls it into question by distinguishing between what she actually experienced herself, and which parts of the puzzle have come from other sources. Here we can ask: why is this important to her? We typically call things into question when something has happened that causes us doubt, or in order to relativize our perspective on things. She perhaps sees herself in a situation in which knowledge is expected from her, and maybe she is afraid she will be unmasked as 'unenlightened'. This would explain why she feels compelled to relativize her knowledge or her memories.

After specifying the aforementioned "we" (Nadija, her sister, and her parents), and giving more 'facts' about where they, and the "whole closer family" (with an emphasis on her grandparents) lived, Nadija says again that her 'own' memories are very few. It is striking that she only mentions 'facts' about her life in Bosnia (they lived in an apartment, she went to kindergarten, and both of her parents worked). So far, she has not mentioned any particular events or emotions. After stressing that her main source of knowledge about her Bosnian past is her parents, she continues with a description of her parents' attachment to their place of origin and cites this attachment as reason. She always imagined $H$. as the "most terrific town in the world". Nadija's laughter not only indicates that this isn't the case anymore, but also that this idealized notion of $\mathrm{H}$. was not justified. In the next sentence, she argues that she struggles to say 'city'. In this case, looking into the original German interview transcript is beneficial: she started to say "die tollste ..." (the most terrific ...), but interrupts herself and continues "der tollste Ort" (the most terrific town ...). Presumably, she initially intended to say 'the most terrific city', since the German article 'die' indicates a feminine noun such as 'Stadt' (city), while neither town ('Ort') nor village ('Dorf') are feminine nouns. Although she explains that it is difficult for her to call it a city (as her parents always do), her first impulse was nevertheless to call H. a city. This leads to the assumption that Nadija has actually internalized the perception her parents imparted to her, even if her present perspective tells her that 
H. is just a town. Subsequently, she tries to reinforce the 'new' viewpoint with facts: the differentiation between village/town and city depends on the number of citizens, and compared to "Western European standards", H. must be regarded as a small town. Here, she draws a symbolic boundary between 'down there' and Western Europe, and the operative factor is most reasonably not 'big' vs. 'small', but something else (since there are big cities in Eastern Europe). It is more likely that this symbolic boundary is between a civilized and progressive life in the (Western European) city and the rural and backward life in the Balkans.

\section{Summary I}

The analysis reveals that the most prominent crisis in Nadija's life regarding the issue of war and migration, seems to be her fragmented knowledge or memory of her Bosnian past - the black box, which evidently also includes the war. It is noteworthy that the war is not mentioned at all in this sequence, not even in the context of migration ("and when I was six years old, we came to Austria"). In one sense, she is focusing on objective facts (place of birth, age at the time of migration, location of the town, lived in an apartment, went to kindergarten, both parents worked). At the same time, she is reflecting upon her memories and her knowledge. She is calling her own knowledge into question; she is doubting her memories, since most of them are derived from the stories of others (her parents). This might explain why she does not narrate stories. There are signs of how deeply she has internalized the stories of her significant others (city vs. town); however, she seems to be simultaneously embarrassed by her own naiveté. Regarding the topic of belonging, she is similarly ambivalent. On the one hand, she emphasizes her familial rootedness in H.; on the other hand, she regards herself (only) as a kind of outsider, since she has no (or very few) memories of her life in Bosnia. Being an outsider and having no (sufficient) insider perspective seems to be problematic for Nadija. Perhaps as a reaction to this ambivalence, Nadija shows a kind of civilizatory superiority at the end of the sequence by drawing a symbolic boundary between the rural place 'down there' and Western European cities.

\subsection{Reality Check}

The subsequent passage from the interview contains a report of her first visit to Bosnia-Herzegovina after the end of war.

So my grandfather, who died in the mean- ah grandfather, who died in the meantime, still has his house there, ahm (1) but there $\mathrm{mm}$ so it is hired out ah for many years now, and if one plainly looks at this house from the outside as well so, $/ / \mathrm{mhm} / /$ we don't really go inside, and it was very hard, for me, to see this town that that always had been like a place of dreams, an idyllic place, where my parents grew up, where they had their terrific circle of friends and everything, and this was suddenly simply an ugly town, since it isn't a beautiful/ place since, $/($ (laughs)) and a, additionally ah, just all persons of 
reference are gone, and also I think, it has a lot to do with the fact, that the first time we came there my parents have been very anxious, they haven't known what to expect, and ahm (1) and I (1) obviously haven't known either ah (1) but, I think, for them it was, for me it was I think just very bad to see that they, that they feel so uncomfortable, ah we also left very fast, and it was every time the same, I think I went there in the meantime all in all five times and it always was exactly the same, at the beginning it was just so that I cried all the time and in the meantime I can go there but, it is not an easy moment and I must prepare myself very well and I know okay, this will come up now I take sedative drops and I am able to look at it, but ahm (1) it hits me, hard, that ah (1) that there is simply, a, yes I believe it, it is ah it is primarily that I have always referred to myself as Bosnian, and always when somebody asked me 'where are you from?' I have always said I am from XYZ, and then, suddenly, I didn't recognize anything and even those things I could remember, looked differently I suddenly somehow that reference origin was completely gone and just a few years ago this was rather a, a big problem for me how I could identify with it.

By repeating the words that her grandfather had died in the meantime, Nadija emphasizes the fact that he is gone. Although he died, he still possesses a house 'there'. It may be assumed that since nobody inherited the house, it is not inhabited by family members. However, it seems to still be a part of the family (history) and a symbol of rootedness. Thus, there is an ambivalence between distance and attachment/bond, and the grandfather serves as a sort of connecting link.

This ambivalence reproduces itself in the following text segment: because the house is "hired out", it can only be viewed from outside. On the one hand, there seems to be a desire to look at the house, to be close to it; on the other hand, entering the house is not possible. It is only observable from an outside(r) perspective. Three aspects of the phrasing stand out: the use of the third person, which indicates that Nadija is not the only one affected by this distant perspective when being close by; the phrase "as well" - it is not only the house, which is viewed from outside, because there are other things that one can only observe from outside; as well as the words "we don't really go inside". What does "not really" mean in this context? Not physically, only in the mind? Regardless, by choosing this wording, she differentiates between a real inside $(r)$ perspective and a perspective that is somewhere between inside and outside. Here, this ambivalence between distance and closeness/attachment is again reproduced, as well as the interpretation according to which Nadija has no experiences or memories of her 'own' - no insider perspective on her Bosnian past. She continues seamlessly and says that it was distressing for her to see this town. By slipping in "for me", she suggests that this may not be the case for others.

After this, Nadija gives three reasons why it was hard for her to be in her hometown. (1) It was aesthetically eye-opening. Her idyllic memory (H. as a "place of dreams, an idyllic place") was shattered. There are no traces of ambivalence here ("and this was suddenly simply an ugly town, since it isn't a beautiful place"). (2) The "terrific" social bonds (of her parents) no longer exist, nor do any relatives still live in H. (3) It was hard for her to see her own parents distressed. One interpretation of this might be that she needs her parents to be "solid as a rock" - especially when 
they are finally back in the familiar surroundings that they had left behind. Her elaborations on her parents' condition, however, are characterized by a peculiar oscillation between relativizing her own consternation (in the sense that the parents are the ones who really suffer, since they lost everything they had) and the ensuing suffering Nadija experiences, on one hand aware of their suffering, and on the other trying to legitimize her own distress.

Her family's approach to dealing with this situation was to leave H. "very fast". Nevertheless, they repeatedly put themselves in the same situation. Nothing changed during those multiple visits; it was "every time the same" or "exactly the same". By preparing herself (by taking sedatives), Nadija at least stopped crying. Here, the question arises as to why she repeatedly puts herself in this situation. Why does she have to "look at it"? She continues by providing further justification (4) about why it "hits [her] hard" - and this might be the most important reason: it is because she has "always referred to [herself] as Bosnian" and during these visits, she "didn't recognize anything". First, it is remarkable that Nadija is not saying something like "because I always felt Bosnian"; it is not about her feelings of belonging, but rather about her 'wrong' self-designation. This self-designation obviously occurred in repeated situations ("always"), when she was asked about her origin ("Where are you from?"). In these situations, she said "I am from H." These remarks suggest that her self-designation as Bosnian or as being from $\mathrm{H}$. was/is not intrinsic, but somehow imposed. It is as though she feels that an unambiguous positioning is demanded from her and she meets this demand by giving an unambiguous answer: I am from $\mathrm{H}$. The visits to $\mathrm{H}$., however, revealed that $\mathrm{H}$. is largely foreign to Nadija. A tension, an ambivalence, occurred between her self-designation as being from $\mathrm{H}$. and the foreignness she experienced during her visits.

\section{Summary II}

Analysis of the first sequence has revealed that the central crisis in Nadija's life seems to be her fragmented knowledge of Bosnia; my interpretation shows that this accompanies an ambivalence regarding the issue of belonging: Nadija emphasizes her familial rootedness in $\mathrm{H}$. and simultaneously regards herself as an outsider due to her lack of memories of Bosnia. This interpretation is confirmed by the second sequence quoted. Analysis of this second sequence shows that Nadija's connection with her Bosnian past is characterized by ambivalence between proximity (emotional as well as spatial) during her visits, and distance (spatial and epistemic, i.e., due to lack of knowledge or lack of an inside(r) perspective). She has a distant perspective from close by. Nadija's emotional proximity is socially derived from her parents, but she is far away; this distance reveals itself during every visit - when she is spatially close. This disclosure of distance is what triggers the crisis that characterizes Nadija's life practice.

In the years following her first visit to H., Nadija tried to (re-)connect with the town that she always imagined as being her hometown, but her attempts failed. What 
she had in mind during all those years in Austria, and what she declared as her hometown when confronted with the question of where she came from, was not based on the actual experience of a hometown, but only on a fading imagination of 'home'. Subsequently, she realigned herself, and named Sarajevo as her new place of origin. While living in Vienna, she built up a circle of friends in Sarajevo and started a relationship with a man from the Bosnian capital. She considered this relationship as a kind of anchor, a connection to the community he unambiguously belongs to. Her attempt to (re-)connect was accompanied by fear of rejection. This anxiety appears repeatedly in Nadija's interview - perhaps most strikingly in the following sequence, which reveals quite clearly why she couldn't simply let Bosnia go.

\subsection{Rejection Anxieties}

First I felt the urge to do my thesis in Sarajevo, and I eventually decided against it ah, since $=\mathrm{I}$ ah, I have had huge fears of failure because I ah have feared that I would not be accepted there as ah as a scientist ..., ahm (1) because I ah, because I grew up in Austria and that I maybe will not be able to comprehend how ah (3) how ah people have been who have been, for instance, in Sarajevo during the war, $/ / \mathrm{mhm} / /$ because I repeatedly have had such experiences in my youth, where ah (2) it has been more or less thrown in, practically, and I was frequently unconsciously ashamed, to haven't had this experience $/ / \mathrm{hm} / / \mathrm{I}$ am of course happy not to have had it but it is ah (1) it was so that I have felt a kind of envy for being here in a safe place and that the experiences of ah ah a refugee ah in diaspora were being understated as something like 'you don't know what real problems are' $/ / \mathrm{mhm} / /$ and ahm (2) and I accepted it like this, that I don't know and that this is a big problem and that I have to know it and I started to deal with it, what exactly happened and how did it happen, and I did not allow myself, for instance, not to look at it, I am really dealing with it, ah, since if I haven't experienced it then a must at least have the strength to know about it.

According to her explanations, Nadija decided not to go to Sarajevo due to a fear of failure and of being rejected. It is, however, remarkable that she was afraid of not being accepted in her profession because she grew up in Austria - as if her growing up in Austria made her a poorer scientist. ${ }^{3}$ Since it is not self-evident why she, as a scientist, must understand how people experienced life during the war, it is conceivable that her decision not to move to Sarajevo has nothing to do with her profession, but that she didn't want to take the risk of not being accepted as really belonging since she did not live through the Bosnian War or the Siege of Sarajevo. Being there and being close would have increased the threat to her imagination of belonging, as with her conception of $\mathrm{H}$. as "the most terrific" place on earth. The following sentence validates this interpretation; the fact that she returns to experiences from her youth confirms the evaluation that it was not about her profession. Her mentions of "such experiences in [her] youth" she "repeatedly" had, are, however, conspicuously vague. Somebody has "more or less" said something to Nadija, although it is not

${ }^{3}$ For reasons of anonymity, I remain vague regarding Nadija's profession. 
clear what has been said. Furthermore, she was "frequently unconsciously ashamed", that is, she only later learned that she was ashamed not to have had "this experience". With "this experience", she obviously does not mean the experience of being confronted with somebody's statements, but the experience of war and siege. It is as though she feels deprived of this experience due to her 'late birth' and her early flight. But since this is not easy to admit (it is not socially acceptable), she interjects that she is "of course" happy not to have had these experiences, and continues that she has also felt guilty for having been safe "here". Once more, she seems to appraise her emotions as inappropriate and proceeds seamlessly with a reference to the experiences of "refugees in diaspora" being understated. Once again, it is not clear who confronted her with such a statement. Actually, this does not seem important to her. It is a fair assumption that this statement about the experience of being a refugee first serves as a kind of justification. Nadija seems to feel a need to point out that she has also suffered, as if suffering (through war and/or forced migration) is considered a condition for belonging. She accepts that people who stayed in Bosnia have gone through much more than herself "who ha[s] been safe". And, at least for a while, she accepted that she "[didn't] know what real problems are" as true. She was convinced that only those who experienced war, who suffered through the war, really know (and really belong). Yet, for that reason, not knowing is a "big problem" for Nadija. She "must know" - it is an imperative which there is no way around. Here, we have a plausible explanation for why she went to H. so many times; why she exposed herself repeatedly to a difficult situation: she couldn't allow herself not to look at it. Even if she cannot remember, even if she did not live through the war, she wants to belong and therefore she must accumulate profound knowledge.

\section{Conclusion}

At the very beginning of the novel, "Kein Meer" (No Ocean), by the BosnianViennese author and journalist, Olja Alvir, the protagonist, Lara Voljić, a young Viennese of Bosnian descent remarks: "I am too young to be entitled to be traumatized by the war. However, I am too old to know nothing about it - too old not to be concerned" (Alvir 2015: 8; Frühwirth/Mijić 2017, 2018). Broadly speaking, Lara is inquiring about the boundaries of her lifeworld, which are substantially defined by war and migration. She is trying to understand what lies within and what lies beyond these boundaries; what she is allowed or able to disconnect from her individual biography, and what she may regard as part of it.

When dealing with the topic of migration and belonging, research typically addresses the problem of inclusion and exclusion in the 'host society'. As further analysis of the interview quite clearly shows, it is indeed essential for Nadija to be considered as belonging to the society she has lived in since her childhood. Simultaneously, however, she wants to be a 'true Bosnian' - and not less so because she is also 
an Austrian. The reconstruction presented in this chapter reveals that (her) doubting of her Bosnian belonging constitutes the central crisis in Nadija's life.

Nadija was six years old when she left Bosnia-Herzegovina. Only a few weeks after her arrival in Austria, she enrolled in an elementary school in the countryside. Against the backdrop of Berger and Luckmann's theory of socialization, we can argue that Nadija started to experience a form of a second primary socialization, i.e., she not only started to learn a new language, but also began to internalize an objective reality that differs in various ways from the objective reality she was surrounded by before migration and the reality her parents imparted to her. Since her parents remain her most important significant others, their reality continued to be effective. The analysis of the very first sequence suggests that Nadija's parents' perception of reality was of utmost importance for her own perception of her Bosnian past, since they were her only connection to it; they constituted the social frame within which she could remember (Halbwachs 1980,1992). Put bluntly, Nadija experienced a doubled (primary) socialization, and it is reasonable to assume that the matter of origin and belonging became highly important to her since this double socialization is not unequivocal. In Social Construction, Berger and Luckmann point out that the "question 'Who am I?' becomes possible simply because two conflicting answers are socially available" (Berger/Luckmann 1966: 186). This observation can also be applied to belonging: to ask "where do I belong?" only makes sense when there are different options for answering this question. This question hardly arises if "the socially predefined answer is massively real subjectively and consistently confirmed in all significant social interactions" (ibid.: 184). Nadija receives contradictory information from her surroundings. In Austria, she sees herself confronted with questions about her origin ("always when somebody asked me "where are you from?"). The question "Where are you from?" implies, for one thing, the assumption that the addressed person - in this case Nadija - is not 'from here'. ${ }^{4}$ Furthermore, it puts an individual in a situation in which they must position themselves, preferably, unambiguously. According to her own account, Nadija met this expectation, at least in her youth. She declared herself as being from H., and developed - influenced by her parents and the fact the family roots were there - an idyllic imagination of her place of origin, although it was far away. During every visit, however, i.e., while being spatially close, the distance between her imaginations and 'reality' became apparent, and with it, the distance between herself and the place she declared as her place of origin. It is the disclosure of distance, the destruction of the idyllic imagination, and of the conviction that this is where she really belongs that triggers the crisis that characterizes Nadija's life practice. Being close by exposes her as an outsider, as someone who does not really belong. This is because belonging (to Bosnia), as understood by Nadija, is characterized by a specific feature: being a true Bosnian seemingly presupposes having experienced the war. This is the reason for her feeling of guilt for not

${ }^{4}$ As a reaction to this question and inspired by the \#metoo movement, in 2019 the hashtag \#vonhier (from here) spread in Germany, where primarily young people shared their stories of being confronted with the question "where are you from?" and all its implications. 
having lived through the war. ${ }^{5}$ Due to her late birth and early flight, she does not consider herself as truly being part of this community of fate. Or, as Olja Alvir, who belongs to the same generation as Nadija, puts it: "I am too young to be entitled to be traumatized by the war." In both cases, it is not the (immediate) experience of war but not having experienced it (sufficiently) that presents a challenge in the construction of biographical identity.

The analysis of further interview passages reveals that Nadija deals with this crisis with her feeling of "incomplete belongingness" - by artificially creating a Bosnian we-identity. Drawing on collective imaginations of ethnic or national affiliation, she defines culture ex ante and tries to comply with it: she wants to speak "beautiful Bosnian", to hear the right music, to watch the right films, to celebrate the right holidays in the right way. In her early teenage years, for instance, Nadija started to read the Qur'an and became religious: she refused to eat pork, she prayed, she asked her mother to wear a headscarf, which her mother refused to do. In her family, religion was non-existent. However, Islam seemed to her to be a means, not of setting herself apart from her Austrian surroundings, but - as the analysis outlined in this chapter suggests - of establishing a stronger bond with what she imagined as her Bosnian origin. There is no way to change not having been there during the war, not having been a part of it. But by persistently working on this problem, by extending her stock of knowledge, and by behaving according to the guidelines this offers, Nadija seemingly hopes to establish a bond which vindicates her considering herself as Bosnian.

Acknowledgments. This article is based on research funded by the Austrian Science Fund (FWF; T 779-G22). I would like to thank Leora Courtney-Wolfman for copyediting.

\section{References}

Alvir, O. (2015): Kein Meer. Wien: Zaglossus.

Berger, P. L./Luckmann, T. (1966): The Social Construction of Reality. A Treatise in the Sociology of Knowledge. New York: Anchor Books.

Bock-Luna, B. (2007): The Past in Exile. Serbian Long-Distance Nationalism and Identity in the Wake of the Third Balkan War. Berlin: Lit-Verlag.

Brubaker, R. (2004): Ethnicity without Groups. Cambridge, MA: Harvard University Press.

Brubaker, R./Cooper, F. (2000): Beyond "Identity". In: Theory and Society, 29(1), $1-47$.

\footnotetext{
${ }^{5}$ Simultaneously, there are also traces of guilt of not having been affected by the war in the same way as those who actually can remember.
} 
Colic-Preisker, V. (2006): "Ethnic" and "Cosmopolitan" Transnationalism. Two Cohorts of Croatian Immigrants in Australia. In: Transnacionalizam i Identitet. Migracijske i etnicke teme, 22(3), 211-230.

Durkheim, É. (1895): Les règles de la méthode sociologique. Paris: Félix Alcan.

Elias, N. (2001): The Society of Individuals. New York: Continuum.

Franz, B. (2005): Uprooted and Unwanted. Bosnian Refugees in Austria and the United States. College Station, TX: Texas A\&M University Press.

Franz, B. (2011): The Bosnian Community in Austria. Linking Integration to Transnationalism. Some Comparative Observations. In: Valenta, M./Ramet, S. P. (eds.): The Bosnian Diaspora. Integration in Transnational Communities. Farnham/Burlington, VT: Ashgate, 143-160.

Frühwirth, A./Mijić, A. (2017): F(r)iktionen. Eine Sozialphysik der Reibungslosigkeit. In: Psychologie \& Gesellschaftskritik, 41(1), 29-48.

Frühwirth, A./Mijić, A. (2018): Reibungsgewinne. Identitäten im Inner[Außer]Halb. In: Momentum Quarterly, 7(2), 98-111.

Hageboutros, J. (2016): The Bosnian Refugee Crisis. A Comparative Study of German and Austrian Reactions and Responses. In: Swarthmore International Relations Journal, 1(1), 50-60.

Halbwachs, M. (1980): The Collective Memory. New York: Harper \& Row.

Halbwachs, M. (1992): On Collective Memory. Chicago: University of Chicago Press.

Halilovich, H. (2013): Bosnian Austrians. Accidental Migrants in Trans-Local and Cyber Spaces. In: Journal of Refugee Studies, 26(4), 524-540.

Halilovich, H./Hasić, J./Karabegović, D./Karamehić-Muratović, A./Oruč, N. (2018): Mapping the Bosnian-Herzegovinian Diaspora (BiH Migrants in Australia, Austria, Denmark, Germany, Italy, Netherlands, Slovenia, Sweden, Switzerland, and the United States of America). Utilizing the Socio-Economic Potential of the Diaspora for Development of BiH. Sarajevo: MHRRBiH.

Ignatieff, M. (1994): Blood and Belonging. Toronto: Penguin Books.

Mannheim, K. (1985): Ideologie und Utopie. 7th ed. Frankfurt a. M.: Klostermann.

Mijić, A. (2014): Verletzte Identitäten. Der Kampf um den Opferstatus im bosnisch-herzegowinischen Nachkrieg. Frankfurt a. M./New York: Campus.

Mijić, A. (2018): Persönliche Identität revisited. In: Endreß, M./Hahn, A. (eds.): Lebenswelttheorie und Gesellschaftsanalyse. Studien zum Werk von Thomas Luckmann. Köln: Herbert von Halem Verlag, 158-191. 
Müller, M./Zifonun, D. (eds.) (2010): Ethnowissen. Soziologische Beiträge zu ethnischer Differenzierung und Migration. Wiesbaden: VS Verlag.

Oevermann, U./Allert, T./Konau, E. (1980): Zur Logik der Interpretation von Interviewtexten. In: Heinze, T./Klusemann, H.-W./Soeffner, H.-G. (eds.): Interpretation einer Bildungsgeschichte. Überlegungen zur sozialwissenschaftlichen Hermeneutik. Bensheim: Päd.-extra, 15-69.

Pryke, S. (2003): British Serbs and Long Distance Nationalism. In: Ethnic and Racial Studies, 26(1), 152-172.

Rosenthal, G. (2004): Biographical Research. In: Seale, C./Gobo, G./Gubrium, J. F./Silverman, D. (eds.): Qualitative Research Practice. London: Sage, 48-64.

Rumbaut, R. G. (1976): The One-and-a-Half Generation. Crisis, Commitment and Identity. In: Rose, P. I. (ed.): The Dispossessed. An Anatomy of Exile. Amherst: University of Massachusetts Press, 331-355.

Rumbaut, R. G. (2004): Ages, Life Stages, and Generational Cohorts.

Decomposing the Immigrant First and Second Generations in the United States. In: The International Migration Review, 38(3), 1160-1205.

Schuetz, A. (1944): The Stranger. An Essay in Social Psychology. In: American Journal of Sociology, 49(6), 499-507.

Schütze, F. (1976): Zur Hervorlockung und Analyse von Erzählungen thematisch relevanter Geschichten im Rahmen soziologischer Feldforschung. In: Arbeitsgruppe Bielefelder Soziologen, Kommunikative Sozialforschung. München: Fink.

Valenta, M./Ramet, S. P. (2011a): Bosnian Migrants. An Introduction. In: Valenta, M./Ramet, S. P. (eds.): The Bosnian Diaspora. Integration in Transnational Communities. Farnham/Burlington, VT: Ashgate, 1-23.

Valenta, M./Ramet, S. P. (eds.) (2011b): The Bosnian Diaspora. Integration in Transnational Communities. Farnham/Burlington, VT: Ashgate.

Verdery, K. (1994): Ethnicity, Nationalism, and State-Making. In: Vermeulen, H./Govers, C. (eds.): The Anthropology of Ethnicity. Beyond "Ethnic Groups and Boundaries". Amsterdam: Het Spinhuis, 33-58.

Weber, M. (1921): Wirtschaft und Gesellschaft. Grundriß der verstehenden Soziologie. Tübingen: Mohr.

Wimmer, A. (2008): The Making and Unmaking of Ethnic Boundaries. A Multilevel Process Theory. In: The American Journal of Sociology, 113(4), 970-1022. 